\title{
Existing Territories and Formalization of Territorial Use Rights for Moored Fish Aggregating Devices: The Case of Small-Scale Fisheries in the La Désirade Island (France)
}

\author{
Guyader Olivier ${ }^{1,{ }^{*}}$, Frangoudes Katia ${ }^{2}$, Kleiber Danika ${ }^{3}$
}

${ }^{1}$ Unité d'Economie Maritime, UMR 6308, CNRS, IUEM, Ifremer, Univ Brest, Plouzané, France

${ }^{2}$ Univ Brest, Ifremer, CNRS, AMURE, IUEM, Plouzane, France

3 JIMAR, PIFSC, Honolulu, HI, USA

*Corresponding author : Olivier Guyader, email address : oguyader@ifremer.fr

\begin{abstract}
:
Moored fish aggregating devices (MFADs) are used by small-scale fishers to access fish species difficult to harvest in large numbers. In the case of Guadeloupe (Caribbean area), the use of MFADs has increased considerably and this is causing congestion in these fishing areas and creating conflict between fishers. The aim of this article is to understand how informal fishing territories around the La Desirade Island were established and examine these territories through the lens of economic defendability theory. Results of semistructured interviews show that MFAD fishers display territoriality along MFAD tract lines forming quasi-privatized areas. Territoriality in this article is based on the following factors: the type of targeted resources, the cost of harvesting, the defending of territories, and the acknowledgment of territories by the fishing community. Conflicts and utilization of MFADs (overcapacity) have raised an opportunity to create co-managed legalized territorial use rights for fisheries.
\end{abstract}

Keywords : : Conflicts, dolphinfish, economic defendability, FADs quotas, overcapacity 


\section{Introduction}

In many parts of the world, including the Caribbean, Moored Fish Aggregating Devices (MFADs) are being used by small-scale fishers to access migratory species (e.g. tunas, dolphinfish) to improve pelagic yields (Rey-Valette et al. 2000; Taquet et al. 2011; Alvard et al. 2015; Guyader et al. 2017). MFADs are human made structures that are tethered to the ocean floor, with a buoy that floats on or near the surface that attract fish (Dempster and Taquet 2004). MFADs create resource patches at known locations, significantly reducing search time, effort and fuel costs for fishers (Alvard et al. 2015). MFAD development programs are seen by scientists and decision makers as a way of increasing the income of small-scale fishers, improving livelihoods in fishing households and communities, and reducing fishing pressure on continental shelves by focusing fishing effort on MFADs (Taquet et al. 2011; Mathieu et al. 2013).

Documentation of MFADs management, including the regulation of the number and density of devices, is particularly rare at the community level (Taquet et al. 2011). Yet, the information on the location and density of MFADs is essential for the management of these devices because they influence individual effectiveness. In high densities, MFADs fish aggregation capacity of each float decreases (Holland et al. 1990; Cayré, 1991; Dagorn et al. 2000), thereby reducing the net benefits of such devices (Guyader et al. 2013). In open access fishing contexts, conflicts can arise between MFAD fishers when densities are high. These conflicts could be mitigated through spatial organization which would include regulations on density, access to, and placement of MFADs (Taquet et al. 2011). 
In the case of Guadeloupe (FAO area 31), individual MFADs were installed in the latter of the 1980s without any accurate knowledge of their number or location (Diaz, 2007; Guyader et al., 2017). This open access to space and fishery expanded in the 1990s resulting in an increasing number of vessels, an extension of fishing areas from nearby coastal waters to more distant coastal areas and a growing number of conflicts between fishers because of MFADs congestion (Diaz et al. 2005; Mathieu et al., 2013). An aerial survey carried out in 2012 around Guadeloupe to estimate MFADs numbers found high densities of MFADs compared with previously reported densities in this area, especially around the northeastern coasts of Guadeloupe off the La Désirade Island (Guyader et al. 2017). According to Guyader et al. (2013), there is no effective MFAD management system nor are there any specific formal rights known associated with territorial usage in this fishery. Because MFAD deployment is not managed, fishers continue to install private MFADs and claim space around them, a reason why informal territories may arise (Christy 2000).

As defined by Dyson-Hudson and Smith (1978) (p. 22), "a territory is an area occupied more or less exclusively by an individual or group by means of repulsion through over defence or some form of communication". Other authors as Begossi (1998) and Turner et al. (2013) analyzed the development of informal fishing territories within the frame of economic defendability theory (Dyson-Hudson and Smith 1978). According to this theory, "territorial behavior is expected when the costs of exclusive use and defense of an area are outweighed by the benefits gained from this pattern of resource utilization" (p. 23). Territoriality is therefore seen as a rational choice of individuals balancing the (marginal) costs and benefits of foraging behavior and territorial defense with the particular distributions of critical resources in space and time. For Dyson-Hudson and Smith (1978), territoriality is an adaptive 
response to environmental factors leading, to high level of territoriality where resources are abundant and predictable, and to nomadic behavior when resources are scarce or unpredictable.

As mentioned by Dyson-Hudson and Smith (1978), variability in territories may be explained by the degree to which territories are exclusive or overlap, defended or non-defended, stable or mobile, permanent or seasonal. The stability of territories and their boundaries may also be influenced by the fishing gears used and type of resources harvested (Acheson 1975; Pollnac 1984). For Turner et al. (2013, p. 493) "while ecological and economic factors are important in the development of territorial behavior, informal territories are commonly regulated by social norms and rules. The ability of groups to create rules and local institutions is therefore important in determining whether systems of territorial behavior arise and whether individuals can benefit from collective action". This is in line with Ostrom (2009) theory on the use of common pool resources, pointed out that the benefits of collective action are conditioned by the fact that formal or informal rights are allocated to individuals or user groups at local level. Formal or informal rights to territories also called Territorial Use Rights for Fisheries (TURFs) are often considered as a means of reducing conflicts over resources and secure the welfare of small-scale fishers (Christy 1982 ; Begossi 2006; FAO 2013) and more generally successful management (Beddington, Agnew and Clark, 2007; Orensanz and Parma, 2010; Orensanz and Seijo 2013). However, Quynh et al. (2017) showed that the effectiveness of TURFs depend on a large number of factors including design features, enforcement and specific contextual fisheries conditions (biology of species, social and economic situation of fishers, institutional arrangements). 
The aim of this article is (1) to understand the presence of informal territories in the MFAD fisheries in Guadeloupe, specifically at the La Désirade Island, (2) to analyze current MFADs territories through the theory of economic defendability (3) to identify the potential drawbacks and opportunities of the current system and assess the findings with the goal of seizing the opportunity to move towards a more formal MFADs co-management system. This work is based on qualitative and quantitative data through semi-structured interviews realized with MFAD fishers and key informants from the La Désirade Island.

\section{Methodology}

\section{Study area}

The island of La Désirade is situated in the Atlantic Ocean, 20 nautical miles east of Guadeloupe (see figure 1), a French overseas region. La Désirade population is estimated approximately at 1,500 people, living on the eastern part of the island. It is the largest fishing community in Guadeloupe with approximately 150 fishers including crew members. Most of the 60 active vessels are between 7 and 9 meters in length and open-decked with powerful outboard engines. Fishing vessel captains own their vessels and crews usually consist of two people. Most of the vessels operate from the main landing port of Beauséjour. The fishing vessels are multipurpose and use several types of fishing gear (Guyader et al. 2013). Traps and pots are used to catch a variety of fish (e.g. parrotfish) and spiny lobsters. Nets and bottom lines are used on the island shelf. Beyond the shelf, fishers use trolling lines and drifting longlines to catch highly migratory pelagic fish around MFADs. In 2012, 33 vessels operated on MFADs and their main target species are common dolphinfish (Coryphaena 
hippurus), yellowfin tuna (Thunnus albacares), blue marlin (Makaira nigricans), filefishes (Canthidermis maculatus) and other species like wahoo (Acanthocybium solandri) (Guyader et al. 2017). Before the development of MFADs, trolling was the traditional way of fishing dolphinfish between December and May. Fishers travelled long distances looking for logs or flocks of birds that would indicate schools of dolphinfish (Taquet et al. 2000).

MFAD regulation in Guadeloupe backs to 1994. It was incorporated in the Prefectural Order of $2002^{1}$ regulating the coastal marine fisheries in the waters of Guadeloupe. According to this regulation (section III article 47), MFADs can be installed by professional fishers after authorization by the Maritime authorities of Guadeloupe. This authorization may be granted after the examination of a mandatory report, which must include the exact position of the devices, their characteristics (including maritime signaling systems) and the identification of the fisher(s) operating around the device(s). According to Guyader et al. (2016), this regulation is poorly enforced and since the 1994 the number of MFADs is not known by the Maritime authorities and also the regional fisheries committee. The MFADs fishery as all other fisheries is also open access, with unlimited entry and no licensing system regulating the number of vessels in the fishery.

\section{Semi-structured interviews with fishers and key informants}

To gather data on the spatial organization of the MFADs in Guadeloupe, semi-structured interviews with local fishers (vessel owners) were conducted in November 2013 and April 2014 by social scientists involved in the project. Even if fishers use French and Creole

\footnotetext{
${ }^{1}$ Arrêté $\mathrm{N}^{\circ}$ 2002/1249 du 19 août 2012 portant réglementation de l'exercice de la pêche maritime côtière dans les eaux du Département de la Guadeloupe. Préfecture de la Région Guadeloupe
} 
language, interviews were realized in French, the official language. The interviews were conducted in the homes of fishing families or at the landing points and lasted between 0.5 2 hours. The selection of fishers to be interviewed was made with the support of the island fishers' association as well as fishery information system data collectors in Guadeloupe ${ }^{2}$. Participants were also selected to represent all four fishing areas (northeast, southeast, southwest, northwest). Maps of the area were shown to the fishers so they could identify their fishing grounds. Vessels length and owner age were also considered in the selection as they may impact the area of operation and conditions of access to fishing grounds. Around $50 \%$ of the reference population of vessel owners $(n=16)$ were interviewed at least twice to complete and cross reference the information provided. The reference population (N) consisted of 33 vessel owners that fished around MFADs in 2012.

The following table provides the characteristics of the respondents, with no significant differences with the non-interviewed population for the set of variables related to vessel owners, vessels and crews. All fishers are French citizens born in Guadeloupe and originate from fisher families of the island.

\footnotetext{
${ }^{2}$ The fisheries information system provides statistics about landings, gears used and effort in Guadeloupe.
} 
Table 1. Characteristics of the respondents and fishers population fishing around MFADs

\begin{tabular}{|c|c|c|c|c|c|c|}
\hline & Vessel age & Horse power $(\mathrm{kW})$ & Vessel length & Vessel owner age & Crew size & Days at sea on MFADs \\
\hline \multicolumn{7}{|l|}{ Respondents ( $\mathrm{N}=16$ ) } \\
\hline Mean & 4.4 & 185 & 8.5 & 36 & 2.1 & 128 \\
\hline Standard deviation & 3.6 & 25 & 0.4 & 9 & 0.3 & 24 \\
\hline \multicolumn{7}{|l|}{ Non-interviewed ( $\mathrm{N}=17)$} \\
\hline Mean & 4,8 & 167 & 8.6 & 41 & 1,9 & 109 \\
\hline Standard deviation & 3.8 & 66 & 1.1 & 11 & 0.4 & 43 \\
\hline \multicolumn{7}{|l|}{ Population ( $\mathrm{N}=33$ ) } \\
\hline Mean & 4.4 & 176 & 8.5 & 37 & 2.1 & 125 \\
\hline Standard deviation & 3.6 & 45 & 0.7 & 8 & 0.4 & 33 \\
\hline Student test ( $p$ value)* & 0.838 & 0.289 & 0.694 & 0.267 & 0.102 & 0.102 \\
\hline Kolmogorov-Smirnov test ( $p$ value)* & 0.999 & 0.122 & 0.593 & 0.313 & 0.999 & 0.052 \\
\hline Wilcoxon test ( $p$ value $)^{*}$ & 0.985 & 0.038 & 0.462 & 0.342 & 0.114 & 0.177 \\
\hline
\end{tabular}

*All the tests were carried using the $R$ software. Student (parametric) and Wilcoxon tests (non-parametric) were carried out to compare the mean characteristics of the respondents to the non-respondents. $p$ values indicate the probability of being wrong in rejecting the null hypothesis (equality of means). The Kolmogorov-Smirnov test was used to test the normality of the samples distributions.

Participants were asked about the number of MFADs they own, their MFAD location strategy and related fishing behaviors, formal and informal rules influencing spatial behaviors, perception of resources availability and observed conflicts and cooperation between fishers. The interviews were transcribed verbatim. Each transcript was read through several times and coded manually following the framework set out by Reismann (2008) for thematic narrative analysis. Where possible, the participant's answers were converted to numeric values. These were included in a database with the obtained characteristics of the respondents. This material was used to carry out descriptive statistics and statistical tests using R software. For each respondent, the position of MFADs and MFADs territories was charted on a map using the QGIS software. To further understand the current spatial distribution, the history of the development and deployment of MFADs around the island were also examined. In addition, six semi-structured interviews were carried out with fishery information system data collectors $(n=2)$, local fish merchants $(n=1)$, fuel/gear suppliers $(n=1)$ and fishers involved in the setting of MFADs $(n=2)$ 


\section{Results}

\section{Emergence and current structure of MFADs territories}

The first MFAD was installed in 1994 by a fisher from Saint François harbor (Guadeloupe main island), in a fishing area frequented by La Désirade fishers during dolphinfish trolling season (see Figure 1). This technique was quickly adopted by other local fishers because of the high catch and reduced fuel costs. These first MFADs were installed in the east-southeast of the island and their immediate success led other fishers to install their own MFADs.

Figure 1. Guadeloupe and first MFAD around La Désirade

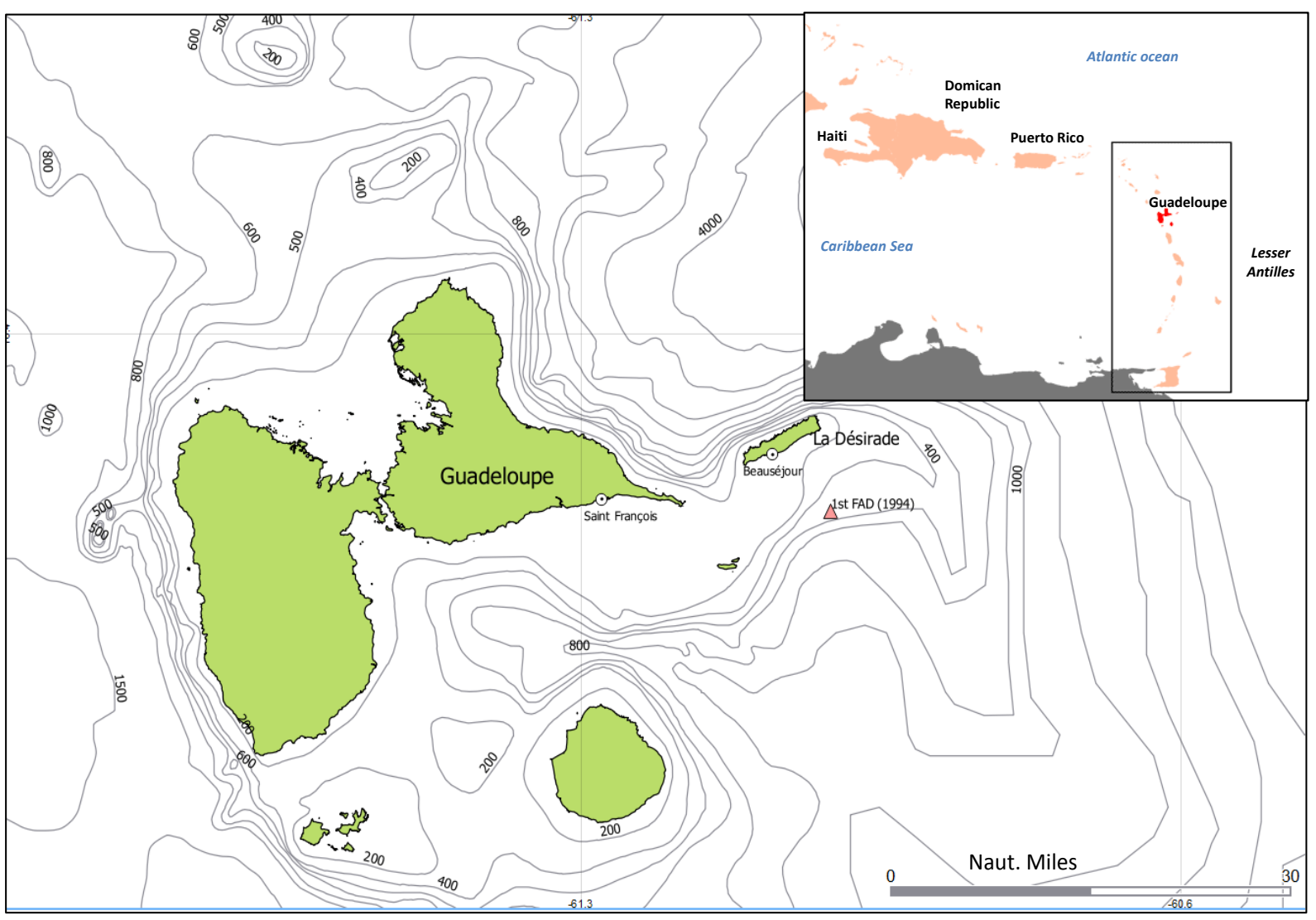

bathymetric lines (GEBCO 2003) in meters 
Fishers considered at least three main factors when choosing MFAD locations: (1) the installation depth for the MFADs; (2) the productivity of the areas; and (3) the location of other fishers' MFADs lines. As shown on the map, bathymetry around La Désirade is heterogeneous, with depths of 200 to 5,000 meters. The cost of investing in a MFAD increases with depth from $500 €, 2000 €, 4500 €$ for a 200, 2000 and 5000 meters depth MFAD respectively. Southeast fishers explained that the lack of space near the island obliged them to place MFADs ever further from the island (up to 40 nautical miles out) and at increasingly higher depths (500 to 2,000 meters) despite the higher cost of installation. Similarly, MFADs were also placed to the east and south. The placement of MFADs to the north and northeast of the island is more recent (early 2000s) with high investments costs.

The second factor to take into account in the location process is the productivity of the area. The migration patterns of the large pelagic target species (dolphinfish, yellowfin tuna, blue marlin, etc.) across the Atlantic Ocean or the Caribbean are influenced by regional and local currents (Taquet et al. 2000). Some fishers $(n=8)$ stated that the furthest east-north-east MFADs are the most productive and are also the first each year to attract the sought-after dolphinfish. One fisher explained: “[M]FAD's located in the North East part of the islands are the most expensive, but most profitable because they are the first to draw in the fish and the price they get at the beginning of the season is very high enough to cover all expenditures" (Fisher interview, 2014). Finally, fishers also considered the remaining available space and location of other fishers' MFADs around the island.

Fisher responses showed that MFADs are highly structured in any given MFAD fishing area. Fishers may set multiple MFADs along a virtual line. Each fisher's MFAD line begins at the main port or where their fishing vessel is anchored. The MFAD then follows a virtual line 
outward towards deeper water (figure 2). On a maritime map, fishers identified their MFAD line, any lines they had set for other fishers, and lines of their neighboring fishers. The start and ending position of these MFADs were cross-referenced with the information gathered by other participants, to provide a complete picture of MFADs fishers' lines. The organization of MFADs, looks like a compass rose encircling the island, with as many lines as there are fishing vessels (figure 2). Each line representing a few degrees distance from the neighboring one and almost all of the area within a 40-45 nautical miles radius of the island is occupied.

Figure 2. MFADs territories around La Désirade in 2014

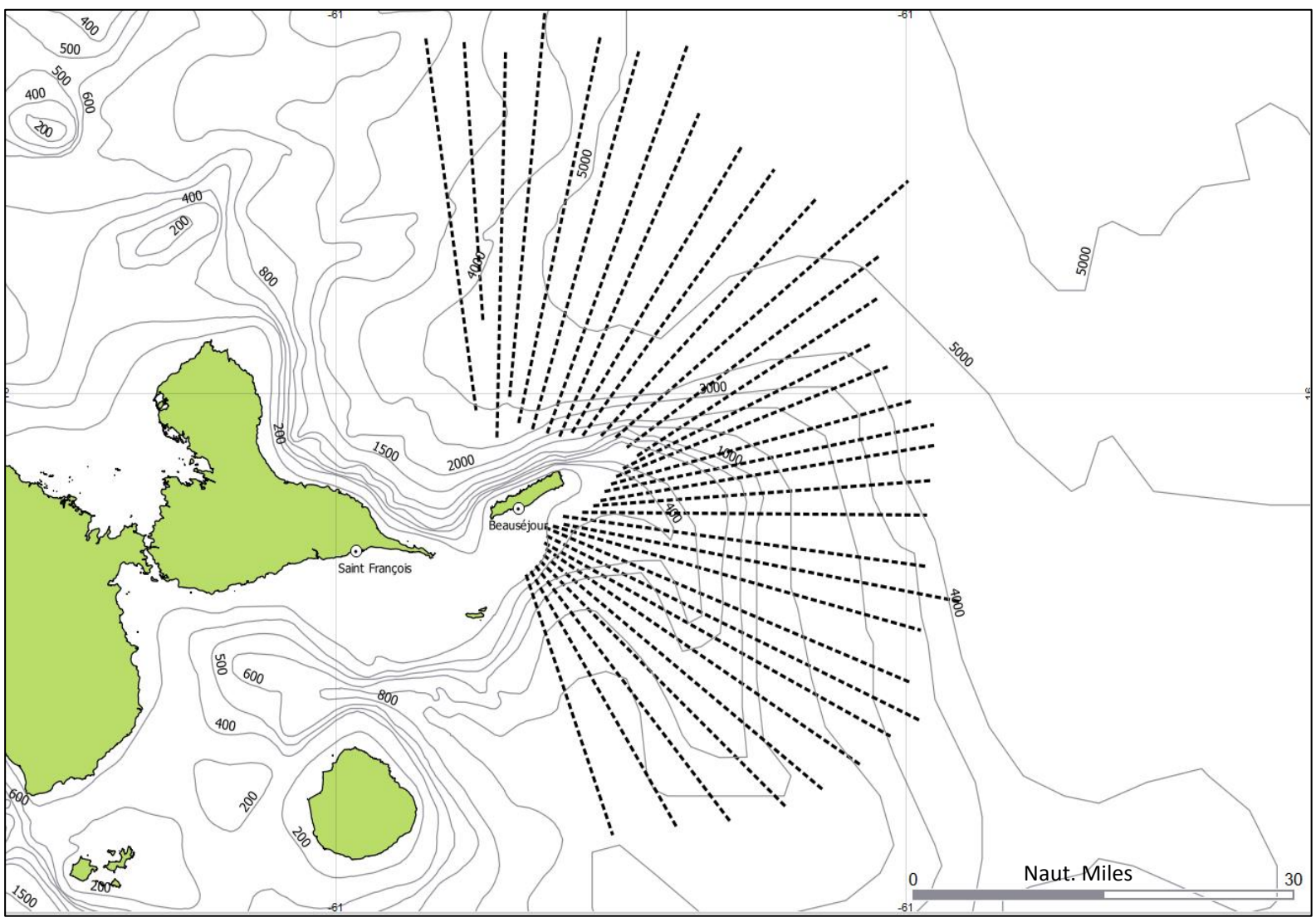

Bathymetric lines (GEBCO 2003)

----- MFADs lines designed from interviews

Six participants mapped the individual MFADs found on their own line beginning at three nautical miles from the island. In each case, MFADs density along a single line is very high 
closer to the island, but decreases with distance. A consequence of this spatial organization is that MFADs close to shore, may also be very close to MFADs belonging to "neighbor lines".

The number of MFADs per fisher varies between 5 and 20 (Mean =10.6, Std dev. = 4.7, $\mathrm{n}=16)$. Although it is not yet possible to accurately estimate the total number of MFADs around the island, a simple extrapolation of the mean figure to the 33 MFADs fishers leads to a preliminary total estimate of 350 MFADs around the La Desirade Island, covering an approximate $5000 \mathrm{~km}^{2}$ area. An aerial survey carried out in 2012 estimated the number of MFADs to 600 around Guadeloupe for a $18000 \mathrm{~km}^{2}$ area $\left(0.02 \mathrm{MFADs} / \mathrm{km}^{2}\right)$ - meaning that MFADs density around the La Desirade Island (0.07 MFADs $\left./ \mathrm{km}^{2}\right)$ is significantly higher than the rest of Guadeloupe. However, the number of MFADs may change throughout the year as fishers lose and/or install new MFADs. Findings indicate that new MFADs tend to be installed when dolphinfish migrate through the area. The number of vessels involved in the fishery is not as high $(\mathrm{N}=33)$ compared the size of the fishing area, but the individual territories are extensive covering very large areas around the island.

\section{Fishing strategies}

All participants described MFAD fishing along their line as a one-day fishing trip for an average of 10 hours. Fishers repeatedly visit MFADs, each fisher along an individual MFAD line. The fishers do this both on their way from the main harbor and back. However, during yellowfin tuna season, some specific MFADs along a line provide higher yields than others leading fishers to adapt their fishing strategy to target those MFADs. Fishing methods around MFADs include trolling lines on the surface, drifting surface hand lines for targeting dolphinfish and small tunas and drifting vertical lines baited with small tunas to catch large yellowfin tunas and incidentally blue marlins. 10 of the fishers who practiced trolling for 
dolphinfish said that pre-MFAD fishing required longer travel distances, even when compared to the current MFAD system with many MFADs on each line. All participants reported fishing on their own MFADs, with some of them $(n=3)$ admitting to fishing occasionally on MFADs belonging to other fishers. Two of these fishers justify this behavior by reasoning that the MFADs in question were perceived to encroach on or cross the MFAD lines of other fishers. All MFADs landings are sold in the main harbor to four local fishmongers.

\section{Exclusivity and recognition of territories}

Most of the participants $(n=11)$ stated that ownership of MFADs conferred "informal" exclusive access to fishing in that area. One participant said that fishers "who have not made the investment do not have the right to fish on my [M]FADs" (fisher interview, 2013), suggesting that MFADs are viewed as private fishing territories. Within this logic some fishers don't hesitate to claim the use of surrounding areas as part of their own territory.

There are additional factors that may strengthen or legitimize the exclusivity of the tract lines. The first is the implicit agreement accepted by the fishing community to recognize a tract line (tracked from a fixed point) to identify a territory. While the course from a fixed point is a practical means of navigation by fishers to go to or move between MFADs, it is primarily a means to claim and ensure that territory is respected. Information on the track lines owned by each fisher is known by all fishers and is clearest between those who are close neighbors. However, MFADs lines are not registered to the fisheries administration, the island fisher's association, or the regional fisheries committee, the main fisher's organization. Within a context where MFADs have no legal status, community recognition, the defense of each territory or at least its preferential use is an important issue. In this case, 
respect of the exclusive use of the territory is more difficult because the areas concerned are very extensive. The high level of competition between fishers gives them valid reasons to maintain the boundaries of their own territories including offshore territories, in order to prevent other fishers from installing their MFADs in and beyond their territories. Fishers are very vigilant and mentioned the use of various land and sea-based preventative measures.

At sea, radio is used to exert authority over territory, preventing MFAD use by third parties, or limiting the passage of other fishers close to these MFADs. Because the fishing community is small and highly concentrated around a single landing point, information about where fishers are fishing and especially if they are fishing around the MFADs belonging to other fishers, circulates quickly. This free flow of information is significantly effective between crews of different vessels, fishers of the same family or between friends. Hence, social control, through informal community monitoring, plays an important role in the cementing of respect for territorial rights of each individual fisher. Infringements on territorial rights are quickly exposed and only a few fishers are willing to bear the brunt of their community's criticism.

Cooperation and collaboration between fishers are also observed. Some of them $(n=4)$ said that surveillance of others fishing ground's is a common practice and others told that they allow others to fish within their territory when they are absent. Territories surveillance and knowledge of 'fishable' MFADs is maintained, and viewed as a potential for reciprocity between fishers, mainly friends or members of the same family. However, the sharing of fishing opportunities is rare and occurs only when the catch is abundant and consists of tunas. This type of cooperation is not possible in the case of dolphinfish because "when a fisher catches dolphinfish, he takes the entire school leaving nothing for the other fishers" 
(Fisher interview, 2013). This "winner takes all" model applies to all fishers because dolphinfish is the main target species in the fishery.

The permanent character of MFADs, anchored to the sea-bed so securely, is another factor contributing to territoriality around MFADs. The anchoring of MFADs to the bottom of the sea and the attached surface buoys represent a form of demarcation of maritime space. Some fishers explained that when they lose a MFAD, they will install another MFAD in the same area in order to occupy the territory and not leave it opened to neighboring fishers.

The possession of territory is strengthened by the identifying characteristics of the floats that give MFADs their buoyancy. These are chosen by individual fishers according to specific shapes, colors and other markings so that they can easily be identified by all fishers on the island as belong to a particular fisher. Although, fisheries regional regulation requires that MFADs be marked, this is only moderately systematic in Guadeloupe. However, the identification of MFADs has increased around the La Désirade in recent years. This is in conjunction with the geographic extension of the fishery in higher depths areas and the installation of mono-buoys with higher floatability, on which it is easier to paint markings. The marking of mono-buoys with vessel name, registration and phone number appears to be a new way of identifying who owns a particular MFAD and operational territory.

The last factor strengthening MFADs territories is that the ownership of the lines can be transferred when a fisher ceases MFAD fishing. Over the 16 participants, 5 benefited from these transfers. Reported transfers occurred between father and son (1 case), between fishers of the same family ( 2 cases) and between fishers with no particular relationship ( 2 cases). When sold ( 2 cases), the lines are given over as a whole and in general valued at the cost of installation of all the MFADs on the line. Because the space available to install new 
MFADs is very limited or located in unfavorable areas, fishers are interested in acquiring lines and associated territories that are more productive or easy accessible. All the new entrants are from the Island and were crew members before entering the MFADs fishery as vessel owners.

\section{Drawbacks of the current system}

The development of MAFDs territories covers a large area of the fishing grounds of the island of La Desirade. The establishment of a high number of MFADs within the maritime space of the island indicates that there is insufficient space for new MFADs. As a result of limited space to set up new MFADs and the subsequent congestion, conflict between fishers in the neighborhood of these MFADs has increased. $90 \%$ of the MFADS fishers responded that conflicts have increased over the last five years.

Younger fishers are also challenged by the current system, because they are forced to place MFADs in remote and deep areas, beyond the territories already appropriated by older MFAD fishers. They consider this ownership, illegal and unfair and contest it openly, leading older MFADs owners to suspect young fishers of not complying with the informal rule of not fishing in territories of other fishers. In interviews, intimidation and sometimes violent conflicts were reported. These occurred both at sea between vessels and on land between fishers. $62 \%$ of participants mentioned they had experienced conflict with other fishers. Although MFAD territories are accepted by the majority of active MFAD fishers, 2 of the 16 fishers feel that the private use of MFADs is illegal, because they are not registered with the relevant authorities and therefore not formally recognized.

Most of the respondents (81\%) felt that the current number and density of MFADs is i) excessive, meaning there is MFADs overcapacity in the fishery and ii) a source of ecological 
and economic problems. For them, MFADs cause a "barrier" by blocking fish at sea from migrating closer to the coast. This statement means that too many MFADs are set in the area. Old fishers who fished when MFADs were first established (4 over the 16 interviewed) recognize that they caught more tuna with fewer MFADs in the past and 5 fishers mentioned catching smaller dolphinfish. Fishers also mention that the cost of maintaining a private line of MFADs has increased due to the increase in the overall number of MFADs and deeper installation depths. Despite the drawbacks of an excessive number of MFADs, the "winner takes all" model encourages fishers to increase MFADs number and position them over a larger area to increase their chances of catching dolphinfish. The consequence is noncooperation for the setting of MFADs (placement, number). The results of this work show that the uncontrolled development of MFADs generates problems of congestion, MFADs overcapacity and conflicts that raise questions of efficiency and equity of the current system.

\section{Discussion}

Perspectives from the theory of economic defendability and social norms

According to general assumptions of the economic defendability model (Dyson-Hudson and Smith 1978), "a (stable) territorial system is most likely under conditions of high resource density and predictability whereas, with unpredictability and low resource density, the territorial tie to a fixed area is not economically defendable and the degree of foraging over a large area must increase (nomadism)". In the case of MFADs, there is a combination of both phenomena with, on the one hand, clearly identified territories along individual private lines and, on the other, fishing strategies characterized by continuous visits (itinerant strategy) during a fishing trip to a large number of aligned MFADs (Guyader et al. 2011). Using the concepts of the economic defendability model, we can define this itinerant behavior as 
"organized nomadism" on a daily fishing trip basis, because fishers operate in their own territory. The current degree of nomadism is high but lower than in the pre-MFADs period where fishers sought out dolphinfish in 'free' schools. However, the degree of nomadism is higher compared to the Martinique (closed French overseas island) MFADs fishery where fishers visit one or two MFADs per day with high and predictable tuna aggregations (Guyader et al. 2017).

Organized nomadism is explained by the relatively large number of MFADs in place, which itself can be explained by the characteristics of the targeted resources. In the case of La Désirade the main target resource is dolphinfish, which is scarce even when aggregated, in contrast to tunas. The spatial distribution of dolphinfish aggregations is unpredictable due to interactions between natural phenomena (migration, currents, floating objects) and MFADs, giving fishers incentives to increase number of MFADs and position them over increasingly larger areas.

The organization of MFADs in lines is less expensive for fishers than scattered MFADs. In a cost-benefit approach to territoriality, it is difficult to separate MFAD line operating costs from those related to territory defense. The main operating cost in MFAD fishing is the cost of fuel and having MFADs positioned in a line lowers fuel usage, making lines less expensive to fish and defend. Territory defense represents a monetary cost (travel to areas to mark and maintain territories, replacement of MFADs, etc.) and non-monetary costs (conflicts with other fishers at sea and on land). The organization of MFADS in lines with a course known by the other fishers and with visible individual markers also facilitates the defendability of the territory because the number of neighbors and confusion over territorial boundaries is limited (although infringements are always possible). However, territoriality 
doesn't limit the number of devices deployed as far there is space available which has been less and less the case over the recent years. Although more detailed information is still required, results suggest that the number of devices in territories is limited by congestion due to proliferation of MFADs. The number of lines is also constrained by the size of the fishing area and the limitation for small-scale vessels to harvest over more distant territories.

As identified in other cases (Begossi 1998), the defense of the territory is also based on cooperative behavior between neighbors or groups of neighbors, who share the duty of territory surveillance and exchange information on catches. Territoriality is also consolidated by social control because fishers are members of the same island community, are often kin related and operate from a single harbor on the island. This may explain why territories are stable over time and generally respected, even if they extend over long distances beyond the immediate vicinity of the coast.

The spatial organization of the La Désirade MFAD fishery in lines is similar to the one found in Mediterranean MFADs dolphinfish fisheries (Morales et al. 2000), but differs significantly from "nucleated" and "perimeter-defended" territories identified by Acheson (1975) in the Maine lobster fishery or group territories linked to fishers home ports in the Northumberland fishery (Turner et al. 2013). This is largely because, in this case, MFADs target highly mobile and migratory species. While spatially different, the MFAD fishery in La Désirade can be similar to the Maine Lobster pot fishery described by Acheson (1975). In both cases informal territories and ownership exist. The absence of a system limiting entry to the fishery means that informal norms about territoriality serve to limit access to the fishery and hence the number of fishers. Unlike the Maine Lobster pot fishery, these informal territories did not limit the number of devices deployed by fishers except when 
there is congestion in territories. The La Désirade MFADs system can also be compared to the Japanese TURFs because in both cases rules are accepted and respected by fishers. But the two systems exemplify two different decision-making processes. In La Désirade rules were produced by the first MFAD fishers, while in Japan rules are agreed upon with within the Fisheries Cooperative Association (Uchida 2007). Furthermore in Japan, territory is defined by law, while in La Désirade MFAD territories are still informal without any formal recognition. Nevertheless, both cases evidence community control and cooperation by means of rules and/or social norms in small-scale fisheries.

\section{Perspectives for formalization of TURFs and their co-management}

The fact that territoriality, based on a de facto private appropriation of space, is stable and recognized by the La Désirade fishing community does not mean that it should not evolve. The results of this work show that current system is characterized by congestion problems, MFADs overcapacity and conflicts that raise questions of efficiency and equity. Moreover, Guyader et al. (2016) showed that territoriality also applies all around Guadeloupe advocating for a co-management of formalized MFADs territories at more global scale than the Desirade fishing community.

The formalization of informal rules is one the strategies proposed by Nielsen (2003) to promote compliance and legitimacy in the fisheries. The legal recognition by the maritime administration of informal territories as localized TURFs around The La Désirade Island, with a maximum number of MFADs authorized by licensed fishers, is a possibility to reduce the total number of MFADs and avoid MFADs overcapacity. Allocation of legalized MFADs lines could be organized through a lottery system (Ruddle, 1987) or based on historical references 
(Poon and Bonzon, 2013). MFADs quota per licensed vessel and per MFADs line could be tried in order to allow a gradual reduction in the number of MFADs.

In order to deal with equity issues, a consolidation of some territories within a formalized TURFs system could also be considered in order to establish collective MFADs in certain areas for fishers excluded from the current MFADs system or who could not afford to invest in their own personal MFADs (Guyader et al. 2013). Successful experiences of collective MFADs shared by fishers exist (Taquet et al. 2011) but previous experiences of collective MFADs in Guadeloupe failed because they were set up without coordination with local fishers association (Gervain and Diaz, unpublished) ${ }^{3}$ especially around La Désirade Island, where MFADs private territories had been established for more than 20 years (Guyader et al. 2017).

This means that the co-management should be participatory including the needs, knowledge, and capacity of local fishers associations (financial, staff, infrastructure, etc.) in order to maintain and sustain over time, the management of the different localized and legalized TURFs around Guadeloupe. As advocated by Christy (1982) a core issue in the decision to create co-managed TURFs is to foster community management at local level and also to define the community that will receive the rights and responsibilities of management of localized TURFs. In La Désirade, many MFAD fishers are members of La Désirade Fisher's Association, but this association is mainly focused on providing services to fishers (ice, MFAD installation...) and has no competency in terms of fisheries management which is given by the French Law to the regional fisheries committee, an elective organization representing fisheries interests (Rural and Fisheries Act 2010). Until now, this Committee has not used its competency towards MFADs spatial management.

\footnotetext{
${ }^{3}$ Gervain P., Diaz N., Parc de DCPs collectifs de Guadeloupe (technologie, surveillance, entretien). Communication to the FADs conference, Tahiti, November 2011.
} 
If co-management at regional (i.e. Guadeloupe) were established, it would be important to re-examine MFAD installation conditions in each area of localized and legalized TURFs (community TURFs) and integrate the local ecological knowledge and practices in the design of the criteria for new installation and management rules (e.g. MFADs quotas per line), including dialogue about the existing system. Fishers' participation in the decision-making process is often necessary for the legitimization of and buy in for fisheries management (Jentoft et al. 1998). Before fisheries organizations and communities can fully engage in comanagement, investment must be made in building capacity, promoting leadership and increasing social capital (Gutierrez et al. 2011, Frangoudes et al. 2013). A first step in this process is that fisheries communities and the regional fisheries committee will be able to discuss problems and projects collectively and also with fisheries decision-makers including the regional maritime administration of Guadeloupe.

\section{Conclusion}

The MFADs territories as they are found in La Désirade are informal because they were created and maintained by local fishers. This study demonstrates that informal rules made by fishers are mostly respected and accepted by the community but not without some contestation by younger fishers and other fishers without access to the most productive territories. This emerging conflict makes it urgent to open discussions between fishers and fisheries administration regarding the formalization of access rules to space and resources as well as redesign the decision-making process by including fishers and their local ecological knowledge of MFAD fisheries. The unequal power relationship, lack of trust between fishers and between the different actors involved in the fishery should also be examined with the 
objective of creating conditions and an environment suitable for more equitable access to the fisheries and distribution of fishing opportunities. Finally, to shift MFAD management from an informal to a formal legalized management system, with the aim of reducing the excessive number of MFADs through MFADs quotas per vessel, it will be necessary to gather more detailed data on the number and location of MFADs. Information on vessel trajectories has been shown to be an effective method of locating MFADs (Guyader et al 2011; Alvard et al. 2015), and should be prioritized in future research. 


\section{Acknowledgements}

The authors would like to thank the anonymous reviewers and editors for the helpful comments and suggestions. This work was funded by the MAGDELESA project on sustainable development of fishing on moored fish aggregating devices in the Lesser Antilles. The MAGDELESA project was co-financed under the INTERREG IV Caribbean program and ERDF. 


\section{References}

Alvard, M., Carlson, D., McGaffey, E., 2015. Using a partial sum method and GPS tracking data to identify area restricted search by artisanal fishers at moored fish aggregating devices in the commonwealth of Dominica. PLoS One 10 (2).

Acheson, J.M., 1975. The Lobster Fiefs. Economic and Ecological Effects of Territoriality in the Maine Lobster Industry. Human Ecology 3(3):183-207.

Beddington, J.R., D.J. Agnew, and C.W. Clark. 2007. Current problems in the management of marine fisheries. Science 316: 1713-1716.

Begossi, A. 1998. Property rights for fisheries at different scales: Applications for conservation in Brazil. Fisheries Res. 34(3):269-278.

Begossi, A. 2006. Temporal stability in fishing spots: Conservation and co-management in Brazilian coastal fisheries. Ecol. Society 11(1):5.

Cayré, P. 1991. Behaviour of yellowfin tuna (Thunnus albacares) and skipjack tuna (Katsuwonus pelamis) around fish aggregating devices (FADs) in the Comoros Islands as determined by ultrasonic tagging. Aquat. Living Resour. 4: 1-12.

Christy, F. 1982. Territorial use rights in marine fisheries: Definitions and conditions. FAO $\begin{array}{lllll}\text { Fisheries } & \text { Technical } & \text { Paper } & \text { No } & \end{array}$ http://www.fao.org/docrep/003/T0507E/T0507E00.HTM (accessed March 2015).

Christy, F. 2000. Common property rights: an alternative to ITQs. In Use of Property Rights in Fisheries Management, eds R. Shotton, pp. 118-137. FAO Fisheries Technical Paper 404/1. 
Code rural et de la pêche Maritime 2010. https://www.legifrance.gouv.fr/

Dagorn L., E. Josse, P. Bach, and A. Bertrand. 2000. Modeling tuna behaviour near floating objects: from individuals to aggregations. Aquat. Living Resour. 13: 203-211

Dempster, T., and M. Taquet. 2004. Fish aggregation device (FAD) research: gaps in current knowledge and future directions for ecological studies. Reviews in Fish Biology and Fisheries 14: 21-42.

Diaz, N., 2007. Rapport National De Guadeloupe: Le Dispositif De Concentration DePoissons Ancrés Artisanal léger Guadeloupéen, In: Report of the SecondMeeting of the WECAFC Ad-hoc Working Group on the Development ofSustainable Moored Fish Aggregating Device Fishing in the Lesser Antilles,Bouillante, Guadeloupe, 5-10 July 2004. FAO $\begin{array}{llll}\text { Fisheries } & \text { Report. } & \text { No } & \text { FAO, Rome23-32 }\end{array}$ http://wwz.ifremer.fr/carafad/Themes/Resources-ecosystems-and-fishing.

Diaz, N., V. Druaut-Aubin, K. Frangoudes, O. Guyader, C. Knockaert, Y. Le Roy, L. Nelson, L. Reynal, R. Walters, A. Lagin, and J.J. Rivoalen. 2005. Main Results from the Work Completed by the "Lesser Antilles" Working Group on the Sustainable Development of Moored FADs Fishing and Perspectives. -In Proceedings of the Fifty Eighth Annual Gulf and Caribbean Fisheries Institute- San Andres Colombia. pp. 237-244 http://procs.gcfi.org/details_view.php?datalD=2390 (accessed March 2015).

Dyson-Hudson, R., and E.A. Smith. 1978. Human territoriality: An ecological reassessment. Am. Anthropol. 80(1):21-41.

FAO. 2013. Implementing improved tenure governance in fisheries - A technical guide to support the implementation of the voluntary guidelines on the responsible governance of tenure of land, fisheries and forests in the context of national food security. 
$\begin{array}{llll}\text { Preliminary } & \text { version, } & \text { September }\end{array}$

http://www.fao.org/docrep/018/i3420e/i3420e.pdf (accessed March 2015).

Frangoudes, K., B. Marugan Pintos, and J. Pascual Fernadez. 2013. Gender in Galician ShellFisheries Transforming for governability, in Governability of fisheries and Aquaculture: Theory and Application. eds M. Banvick, R. Chuenpagdee, S. Jentoft and J. Kooiman, pp. 241-261, MARE Publications Series 7, Springer.

Gutierrez, N.L., Hilborn, R., and O Defeo. 2011. Leadership, social capital and incentives promote successful fisheries. Nature 470, 386-389.

Guyader O., L. Reynal, P. Berthou, E. Leblond, M. Bellanger, A. Campéas, B. Angin, L. Quemener, and M. Pitel-Roudaut. 2011. Exploring fishermen behaviour around moored FADs: the example of air plane surveys and vessels positioning system in Guadeloupe and Martinique. Communication to the FADs conference, Tahiti, November 2011.

Guyader, O., M. Bellanger, L. Reynal, S. Demanèche, and P. Berthou. 2013. Fishing strategies, economic performance and management of moored fishing aggregating devices in Guadeloupe. Aquatic Living Resources 26: 97-105

Guyader, O., R. Bauer, and L. Reynal. 2017. Assessing the number of moored fishing aggregating devices through aerial surveys: A case study from Guadeloupe. Fisheries Research. 185, 73-82.

Holland, K.N., R.W. Brill, and R.K.C. Chang. 1990. Horizontal and vertical movements of yellowfin and bigeye tuna associated with fish aggregating devices. Fish. Bull. U.S. 88: 493-507.

Jentoft, S., B. McCay, and D. C. Wilson 1998. Social theory and fisheries co-management, Mar. Policy, 22(4-5): 423-436. 
Mathieu, H., Reynal, L., Magloire, A., Guyader, O., 2013. Does FAD deployment havea real effect on fishing redeployment towards offshore resources? In: Proceedings of the 66th Gulf and Caribbean Fisheries Institute, November 4-8,2013 Corpus Christi, Texas USA, pp. 511-517.

Morales-Nin, B., Cannizaro, L., Massuti, E., Potoschi, A.F., Andaloro, F., 2000. Anoverview of the FADs fishery in the Mediterranean Sea. In: Le, J.-Y., Gall Cayré,P., Taquet, M. (Eds.), Pêche Thonière Et Dispositifs De Concentration DePoissons. , pp. 184-207.

Nielsen, J. R. 2003. An analytical framework for studying: compliance and legitimacy in fisheries management. Mar. Policy 27: 425-432

Orensanz, J.M., and A.M. Parma. 2010. Chile Territorial use rights. Successful experiment? Samudra 55: 42-46.

Orensanz, J. M. and J. C. Seijo. 2013. Rights-based management in Latin American fisheries. FAO Fisheries and Aquaculture Technical Paper, No. 582. Rome, FAO.

Ostrom, E. 2009. A General Framework for Analyzing Sustainability of Social-Ecological Systems. Science 325: 419-422

Poon, S. E. and Bonzon, K. 2013. Catch Share Design Manual, Volume 3: Territorial Use Rights for Fishing. Environmental Defense Fund.

Pollnac, R.B. 1984. Investigating territorial use rights among fishermen. In Maritime institutions in the Western Pacific. eds. K. Ruddle, and T. Akimichi, pp. 285-300. Senri Ethnological Studies 17, Osaka, Japan: National Museum of Ethnology.

Quynh, C. N. T., Schilizzi, S., Hailu, A., Iftekhar, S. 2017. Territorial Use Rights for Fisheries (TURFs): State of the art and the road ahead. Marine Policy 75: 41-52

Reissman, C. K. 2008. Narrative Methods for the Human Sciences. Thousand Oaks, CA: Sage. $264 \mathrm{pp}$ 
Rey-Valette, H., E. Cillaurren, and G. David. 2000. Multidisciplinary assessment of the sustainability of small-scale fishery around anchored FADs. Aquatic Living Resources 13: $241-252$

Taquet, M., L. Reynal, and M. Laurans 2000. Do FADs influence the geographical distribution of dolphinfish (Coryphaena hippurus)? In Pêche thonière et dispositifs de concentration de poissons, eds. J-Y. Le Gall, P. Cayre, and M. Taquet, pp. 528-536. Ifremer, Actes Colloq. 28. http://archimer.ifremer.fr/doc/00042/15321/ (accessed March 2015).

Taquet, M., M. Blanc, L. Dagorn, J. D. Filmalter, A. Fonteneau, F. Forget, J. C. Gaertner, R. Galzin, P. Gervain, M. Goujon, P. Guillotreau, O. Guyader, M. Hall, K. Holland, D. Itano, J.P. Monteagudo, B. Morales-Nin, L. Reynal, M. Sharp, W. Sokimi, M. Tanetoa, and S. Yen Kai Sun. 2011. Artisanal and industrial FADs: A question of scale. Tahiti conference reviews current FAD use and technology. Fisheries Newsletter 136: 35-45. http://archimer.ifremer.fr/doc/00115/22657/

Turner R. A., T. Gray, V. C. Nicholas, N.V. Polunin, M. Selina, and S. M. Stead. 2013. Territoriality as a Driver of Fishers' Spatial Behaviour in the Northumberland Lobster Fishery. Society \& Natural Resources: An International Journal. 26(5): 491-505.

Uchida, H. 2007. Collective fishery management in TURFs: The role of effort coordination and pooling arrangements. PhD diss., University of California, Davis. 